\title{
The lichen genus Kroswia is a synonym of Fuscopannaria (Pannariaceae)
}

\author{
Nicolas MAGAIN and Emmanuël SÉRUSIAUX
}

\begin{abstract}
Molecular inferences of three loci within a phylogenetic framework of a subset of the Pannariaceae confirm that the genus Kroswia is nested within the genus Fuscopannaria. The formal combination of the type species of Kroswia into Fuscopannaria is therefore made here, and Kroswia is reduced into synonymy with the latter genus.
\end{abstract}

Key words: ascomycota, cyanolichens, morphology, Nostoc, Peltigerales, taxonomy

Accepted for publication 6 October 2014

\section{Introduction}

A persistent question in the Pannariaceae, a well-known and cosmopolitan lichen family, lies with the assignment of taxa with collematoid thalli, that swell considerably and form gelatinous masses when wet and quickly return to a crispy and fragile form when dry, unlike typical members of the family that develop a 'pannarioid' thallus that does not swell when wet (Wedin et al. 2009; Otálora et al. 2010). Species in the genus Kroswia P. M. Jørg. develop thalli of the former type, typically homoiomerous with an indistinct cortex, the photobiont forming chains of cells with much swelling sheaths and present thoughout the thallus; species with a typical 'pannarioid' thallus such as in the genus Fuscopannaria P. M. Jørg. develop heteromerous thalli with a distinct upper cortex and a very distinct photobiont layer with photobiont cells compacted and assembled in clusters.

A further interesting matter within the same family is the occurrence of tripartite thalli, which are lichenized with green algae but produce well-differentiated structures, usually referred to as cephalodia, which are

N. Magain and E. Sérusiaux : Evolution and Conservation Biology, University of Liège, Sart Tilman B22, B-4000 Liège, Belgium.

Email : Nicolas.Magain@doct.ulg.ac.be lichenized with cyanobacteria usually belonging to the genus Nostoc. Such cephalodia may develop thalloid forms, sometimes produce fragments that act as vegetative diaspores (Jørgensen \& Wedin 1999), or may resemble autonomous entities recognized as a different genus, namely Santessoniella Henssen.

A recent study conducted by the authors (Magain \& Sérusiaux 2014) could provide strong support for two interesting evolutionary patterns within that family. Indeed, a photobiont switch between two different strains of Nostoc is suspected to be the driver for the change in thallus type (pannarioid thallus to collematoid type) within a strongly supported clade comprising the genera Fuscopannaria, Kroswia, Leciophysma Th. Fr. and Protopannaria (Gyeln.) P. M. Jørg. \& S. Ekman. Photobiont switches have been shown or are suspected to play a crucial role in speciation processes of lichens (examples in $\mathrm{Ba}-$ loch \& Grube 2006; Nelsen \& Gargas 2008; Fernández-Mendoza et al. 2011; Printzen et al. 2013) and the molecular inferences in a phylogenetic context do support such a scenario for the genus Fuscopannaria.

Furthermore, cephalodia emancipation from ancestral tripartite thalli followed by divergence is supported by the data and may represent an evolutionary pattern present throughout the family; it may explain the 
morphological resemblance between the thalli of several genera with cephalodia of others, as well as the complex phylogenetic relationships between species with tripartite thalli and others with collematoid or pannarioid thalli. A convincing example of this evolution pattern is provided by the free-living Santessoniella polychidioides (Zahlbr.) Henssen, lichenized with Nostoc, which is nested with strong support within the tripartite genus Psoroma Ach. ex Michx. (Ekman et al. 2014) and can be interpreted as the emancipated cephalodia of its tripartite ancestor which eventually diverged.

This study aims to confirm the finding by Magain \& Sérusiaux (2014) that the collematoid genus Kroswia is nested in Fuscopannaria and to resolve their relationships by producing a phylogenetic tree including all data available in Fuscopannaria. As three accessions of its type species (K. crystallifera P. M. Jørg.) are found nested within Fuscopannaria with strong support, the taxonomic and nomenclatural conclusions are drawn in this paper.

\section{Material and Methods}

All sequences used in the phylogenetic analyses were downloaded from GenBank (Table 1). Those produced by Ekman et al. (2014) in a revised classification of Pannariaceae and Magain \& Sérusiaux (2014) for the taxa dealt with in this paper are thus included. We assembled a concatenated matrix of three loci: $\mathrm{mtSSU}$, nuLSU and RPB1 using MacClade v. 4.08 (Maddison \& Maddison 2005). Ambiguously aligned positions were delimited by eye and excluded from the phylogenetic analyses. The alignment was divided into six subsets: $\mathrm{mtSSU}$, nuLSU, $R P B 1$ 1st, 2nd and 3rd codon positions, and the intron in $R P B 1$. The best partition for the dataset was estimated using PartitionFinder (Lanfear et al. 2012) using AICc as a criterion and testing all models available with the greedy algorithm. The partition selected consisted of 5 subsets: LSU and the 1 st codon of RPB 1 together, and every other subset by itself.

We produced a best ML tree using RaxML-HPC2 v. 8.0.24 (Stamatakis 2006; Stamatakis et al. 2008) as implemented on the CIPRES portal (Miller et al. 2010), using the GTRGAMMA model and 1000 bootstrap iterations. A Bayesian analysis was performed using MrBayes v. 3.2.2 (Huelsenbeck \& Ronquist 2001) as implemented on the CIPRES portal, running for 20 million generations with two runs of three cold chains and one heated chain each, and sampling every 1000th generation. The first
$25 \%$ of the trees sampled were discarded as burn-in, and a $50 \%$ consensus tree was produced using the remaining trees. Convergence of the analyses was assessed using Tracer (Rambaut \& Drummond 2007) and AWTY (Nylander et al. 2008) as implemented on the website http://king2.scs.fsu.edu/CEBProjects/awty.

\section{Results}

The phylogenetic tree (Fig. 1) presented here is the Bayesian $50 \%$ consensus tree with evaluation of branch support from the Maximum Likelihood results and the posterior probabilities of the Bayesian search; 2666 characters from four loci $(5.8 \mathrm{~S}, \mathrm{mtSSU}$, nuLSU and $R P B 1)$ are included for 42 accessions representing 38 taxa.

As in earlier studies (Ekman et al. 2014; Magain \& Sérusiaux 2014), the genus Fuscopannaria is retrieved as a monophyletic group, divided into two strongly supported clades, accepting that $F$. sampaiana (Tav.) P. M. Jørg. is assigned to a different genus (Nevesia: Ekman et al. 2014) and with the exception of F. laceratula (Hue) P. M. Jørg. which is resolved within a strongly supported and related lineage comprising Protopannaria pezizoides P. M. Jørg. \& S. Ekman. The first clade within Fuscopannaria includes, among others, the type species $[F$. leucosticta (Tuck.) P. M. Jørg.] and the three accessions of Kroswia crystallifera, whilst the second one includes, among others, the monotypic genus Moelleropsis nebulosa (Hoffm.) Gyeln.

\section{Synonymy of Kroswia and new combination in the genus Fuscopannaria}

The phylogenetic relationship of Kroswia crystallifera, the type species of Kroswia, is similar to Moelleropsis nebulosa: although the overall morphology strongly deviates from the typical pannarioid thallus type of all species assigned to that genus, the molecular data leave no doubt that both species must be subsumed into Fuscopannaria (Ekman et al. 2014; Magain \& Sérusiaux 2014). Data on apothecial characters provided by Jørgensen $(2007 a)$ on another species $[K$. 
TABLE 1. Table of the voucher specimens used in this study, with the species names and references to original publications; GenBank accessions of the sequences.

\begin{tabular}{|c|c|c|c|c|c|}
\hline Taxon & Country & Publication & $\begin{array}{c}\text { GenBank } \\
\text { mtSSU }\end{array}$ & $\begin{array}{l}\text { Accession } \\
\text { LSU }\end{array}$ & $\begin{array}{l}\text { Number } \\
\text { RPB1 }\end{array}$ \\
\hline Fuscoderma applanatum & New Zealand & Wedin et al. 2009 & GQ259024 & GQ258994 & GQ259053 \\
\hline Fuscopannaria ahlneri & South Korea & Wedin et al. 2009 & GQ259025 & GQ258995 & GQ259054 \\
\hline F. cheiroloba & & Ekman et al. 2014 & - & - & KC608113 \\
\hline F. confusa & Norway & Carlsen et al. 2012 & GU570043 & - & - \\
\hline F. ignobilis & & Miądlikowska et al. 2006 & DQ917416 & DQ917417 & DQ986839 \\
\hline F. lacerulata & & Ekman et al. 2014 & KC608070 & - & KC608115 \\
\hline F. leucosticta 1 & Reunion Island & Magain \& Sérusiaux 2014 & JX494238 & JX494264 & JX494284 \\
\hline F. leucosticta 2 & USA & Wedin et al. 2009 & DQ900630 & DQ900640 & GQ259055 \\
\hline F. leucostictoides & & Ekman et al. 2014 & KC608071 & - & KC608116 \\
\hline F. maritima & & Ekman et al. 2014 & KC608072 & - & KC608117 \\
\hline F. mediterranea & & Miądlikowska et al. 2006 & DQ917418 & DQ917419 & - \\
\hline F. olivacea & & Ekman et al. 2014 & KC608073 & - & - \\
\hline F. pacifica & & Ekman et al. 2014 & KC608074 & - & KC608118 \\
\hline F. praetermissa 1 & Reunion Island & Magain \& Sérusiaux 2014 & JX494239 & - & JX494285 \\
\hline F. praetermissa 2 & Sweden & Wedin et al. 2009 & GQ259026 & GQ258996 & GQ259056 \\
\hline F. protensa & & Ekman et al. 2014 & - & - & KC608119 \\
\hline F. sorediata & & Ekman et al. 2014 & KC608067 & - & - \\
\hline Kroswia crystallifera 1 & Madagascar & Magain \& Sérusiaux 2014 & JX494235 & JX494261 & JX494281 \\
\hline K. crystallifera 2 & Reunion Island & Magain \& Sérusiaux 2014 & JX494236 & JX494262 & JX494282 \\
\hline K. crystallifera 3 & Reunion Island & Magain \& Sérusiaux 2014 & JX494237 & JX494263 & JX494283 \\
\hline Leciophysma furfurascens & Sweden & Wedin et al. 2009 & GQ259028 & GQ258998 & GQ259058 \\
\hline Moelleropsis nebulosa & & Ekman et al. 2014 & KC608079 & - & KC608122 \\
\hline Nevesia sampaiana & Norway & $\begin{array}{l}\text { Carlsen et al. } 2012 \text { / } \\
\text { Ekman et al. } 2014\end{array}$ & GU570030 & - & KC608120 \\
\hline Pannaria calophylla & Argentina & Passo et al. 2008 & EU885318 & - & - \\
\hline P. implexa & Argentina & Passo et al. 2008 & EU885333 & - & - \\
\hline P. lurida & Reunion Island & Magain \& Sérusiaux 2014 & JX494248 & JX494273 & - \\
\hline P. microphyllizans & Argentina & Passo et al. 2008 & EU885322 & - & - \\
\hline P. multifida & Reunion Island & Magain \& Sérusiaux 2014 & JX494241 & JX494266 & KF704308 \\
\hline P. pallida & Argentina & $\begin{array}{l}\text { Passo et al. } 2008 \text { / } \\
\text { Elvebakk et al. } 2010\end{array}$ & EU885323 & GQ927270 & - \\
\hline P. rubiginella & & Wedin et al. 2009 & GQ259037 & GQ259007 & GQ259074 \\
\hline P. rubiginosa & Portugal & Wedin et al. 2009 & AY340513 & AY340558 & GQ259073 \\
\hline$P$. sp. & Thailand & Magain \& Sérusiaux 2014 & KF704289 & KF704290 & KF704306 \\
\hline P. sphinctrina & Argentina & $\begin{array}{l}\text { Passo et al. } 2008 \text { / } \\
\text { Elvebakk et al. } 2010\end{array}$ & EU885324 & GQ927271 & - \\
\hline P. tavaresii & Argentina & Passo et al. 2008 & EU885316 & - & - \\
\hline Parmeliella parvula & Norway & Carlsen et al. 2012 & GU570031 & - & - \\
\hline Protopannaria pezizoides & Sweden & Wedin et al. 2009 & AY340519 & AY340561 & GQ259081 \\
\hline Psoroma hypnorum & Sweden & Wedin et al. 2009 & AY340523 & AY340565 & GQ259085 \\
\hline P. palaceum & Argentina & Passo et al. 2008 & EU885327 & GQ927305 & - \\
\hline Ramalodium succulentum & Australia & Wedin et al. 2009 & GQ259043 & GQ259013 & GQ259086 \\
\hline Santessoniella sp. & & Ekman et al. 2014 & KC608105 & - & KC608146 \\
\hline Staurolemma omphalarioides & Norway & Wedin et al. 2009 & GQ259044 & GQ259014 & - \\
\hline S. sp. & Reunion Island & Magain \& Sérusiaux 2014 & KF704288 & KF704291 & - \\
\hline
\end{tabular}

gemmascens (Nyl.) P. M. Jørg.] referred to that genus are congruent: hymenium I+ blue-green rapidly turning red-brown, asci with an amyloid ring structure. Two characters of the ascospores do deviate as they are globose and pale brown in K. gemmascens, while they are ellipsoid without any colour in Fuscopannaria leucosticta, F. praetermissa
(Nyl.) P. M. Jørg. and other related species (Jørgensen 2007b). Furthermore they lack a perispore, which makes a difference for many species of Fuscopannaria. The value of these characters have never been tested in a phylogenetic context, and they are thus difficult to interpret. They might be speciesspecific within the genus, or represent 


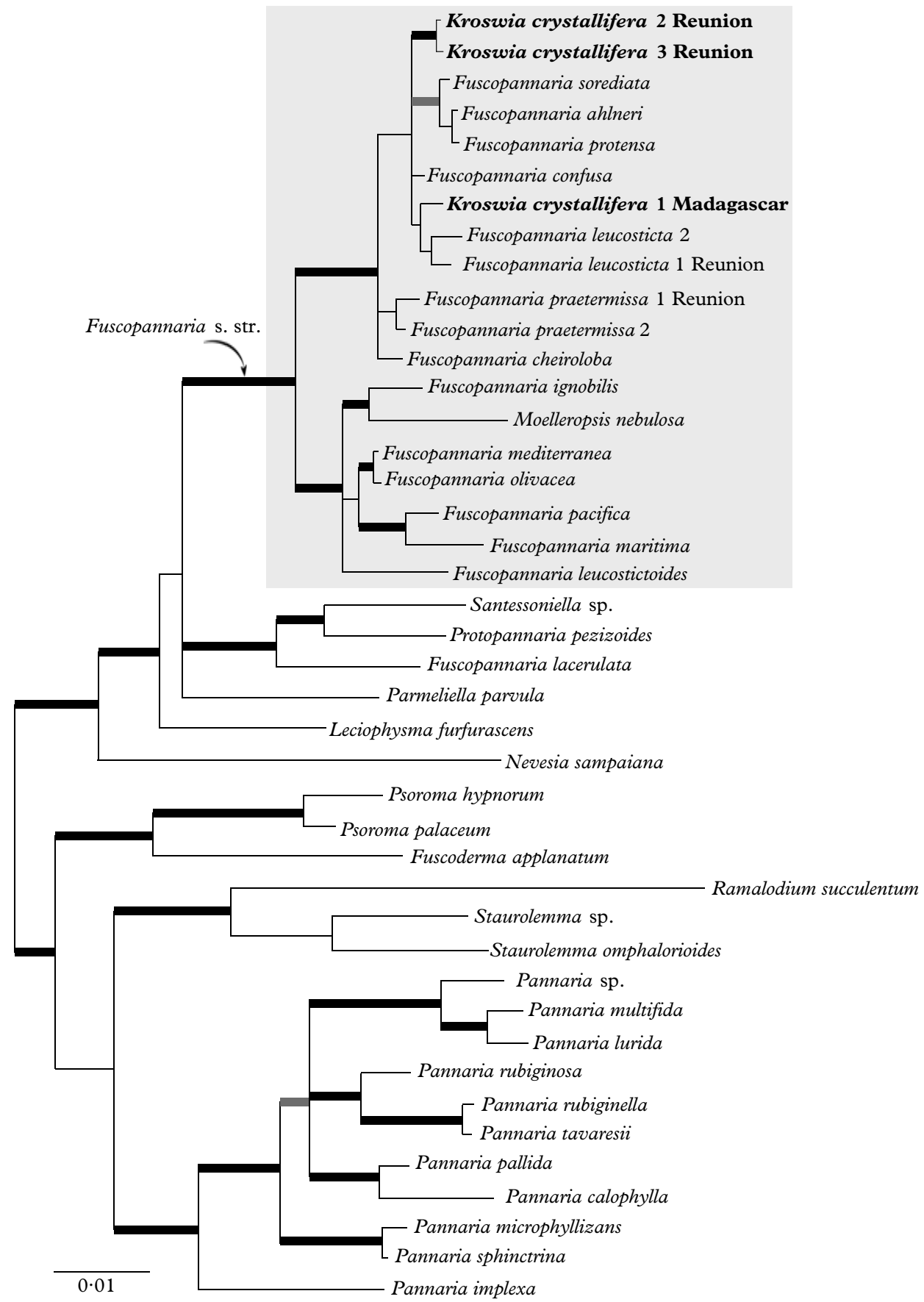

FIG. 1. 50\% consensus tree resulting from the Bayesian analysis of $\mathrm{mtSSU}$, LSU and RPB1 on representatives of the family Pannariaceae. The genus Fuscopannaria is highlighted. Rooting follows Magain \& Sérusiaux (2014). Thick black branches have a Posterior probability $>0.95$ and a Maximum Likelihood bootstrap $>70$. Thick grey branches have a PP $>0.95$ but MLBS $<70$. 
autapomorphies for a further generic entity within the Fuscopannaria clade. Certainly, the genus has no close relationship with the Pannaria lurida (Mont.) Nyl. group as previously assumed (Jørgensen 2002), as this group is resolved with strong support within Pannaria Delise ex Bory s. str.

A detailed description of Kroswia is available in Jørgensen (2002). Three species are currently recognized in the genus: $K$. crystallifera, known from Kenya, South Africa, Reunion, India/Tamil Nadu, Sri Lanka, Taiwan, Papua New Guinea and Australia (Jørgensen \& Sipman 2006) and also Madagascar (Magain \& Sérusiaux 2014); K. gemmascens, reported from Japan and China/Sichuan and Xizang (Jørgensen 2007a); and K. polydactyla P. M. Jørg., described and known only from New Caledonia (Jørgensen \& Gjerde 2012). The collematoid thallus of $K$. crystallifera (Fig. 2A) is homoiomerous, with a hardly distinct epicortex, or no cortex at all, with individual chains of Nostoc easily distinguished and spreading throughout the height of the thallus. Such a thallus is very different from the closely related species which have a distinct, multi-layered cortex and a welldelimited layer containing Nostoc cells, with hardly any chains distinguishable (Magain $\&$ Sérusiaux 2014).

Interestingly, Kroswia crystallifera is closely related to the type species of Fuscopannaria (F. leucosticta, Fig. 2A), and to other species grouped together as an unresolved polytomy [F. ahlneri (P. M. Jørg.) P. M. Jørg., F. cheiroloba (Müll. Arg.) P. M. Jørg., F. confusa (P. M. Jørg.) P. M. Jørg., F. praetermissa, F. protensa (Hue) P. M. Jørg., F. sorediata P. M. Jørg.]. The hypothesis that $F$. crystallifera evolved from a duo of photomorphs, formed by the very same fungus and lichenized with two different strains of Nostoc that eventually dissociated and diverged, cannot be ruled out. Both photomorphs may even have formed a single thallus, such as in the case of cyanochlorolichens (Henskens et al. 2012) or in cases of co-existence of two different photobionts within a single thallus [Casano et al. 2011; del Campo et al. 2013 for Ramalina farinacea (L.) Ach.]. Furthermore, another switch between different strains of Nostoc within the clade of Fuscopannaria is likely to explain the very different thallus of Moelleropsis nebulosa, formed by coarse, usually dispersed granules, as this monotypic genus is nested within the second group recognized within Fuscopannaria.

As no molecular data are available for Kroswia gemmascens and $K$. polydactyla, we refrain from formally proposing the combination of both epithets to Fuscopannaria. Indeed, the Pannariaceae have reserved so many surprises regarding its evolutionary patterns that proposing hardly confirmed nomenclatural changes must be avoided.

Moelleropsis Gyeln. is a monotypic genus and is an older name than Fuscopannaria; a conservation proposal has been formally made (Jørgensen et al. 2013) and we therefore maintain the use of Fuscopannaria for this widespread and well-known species clade.

\section{Fuscopannaria P. M. Jørg.}

f. Hattori Bot. Lab. 76: 198 (1994); type: Fuscopannaria leucosticta (Tuck.) P. M. Jørg.

Kroswia P. M. Jørg., Lichenologist 34: 297 (2002), syn. nov.; type: Kroswia crystallifera P. M. Jørg.

Fuscopannaria crystallifera (P. M. Jørg.) Magain \& Sérus. comb. nov.

\section{MycoBank No.: 809865}

Kroswia crystallifera P. M. Jørg., Lichenologist 34: 299 (2002); type: India, Tamil Nadu, Palni Hills, 23 January 1975, M. E. Hale 43843 (US-holotype!)

(Fig. 2A)

Selected material examined of Fuscopannaria crystallifera: Madagascar: Angavokely Forest Station, $18^{\circ} 55^{\prime} 37 \cdot 9^{\prime \prime} S$, $47^{\circ} 44^{\prime} 15 \cdot 2^{\prime \prime} \mathrm{E}$, alt. $1770-1780 \mathrm{~m}$, degraded ericaceous shrub near the summit, 2008, E. Sérusiaux s. n. with $E$. Fischer, D. Ertz, D. Killmann \& V. Razafindrahaja (LG M788).--Réunion: Cirque de Cilaos, Forêt du Grand Matarum, $21^{\circ} 07 \cdot 416^{\prime} \mathrm{S}, 55^{\circ} 28 \cdot 983^{\prime} \mathrm{E}$, alt. $1400-1450$ $\mathrm{m}$, disturbed montane forest, 2008, E. Sérusiaux with M. Brand E P. van den Boom (LG R1055); ibid., Col de Taibit, $21^{\circ} 06^{\prime} 42 \cdot 5^{\prime \prime} \mathrm{S}, 55^{\circ} 26^{\prime} 34 \cdot 0^{\prime \prime} \mathrm{E}$, alt. $1800 \mathrm{~m}$, disturbed montane forest, N. Magain $\mathcal{E}$ E. Sérusiaux (LG R1679).

Field studies in Reunion were made possible with the help and advice of the "Parc National de La Réunion", especially through the courtesy of Mr B. Lequette. Dr Cl. Ah-Peng and Prof. D. Strasberg of the University of La Réunion in Saint-Denis, and Dr J. Hivert of the Conservatoire Botanique National de Mascarin (St-Leu) were also very helpful. A first field trip to Reunion in 

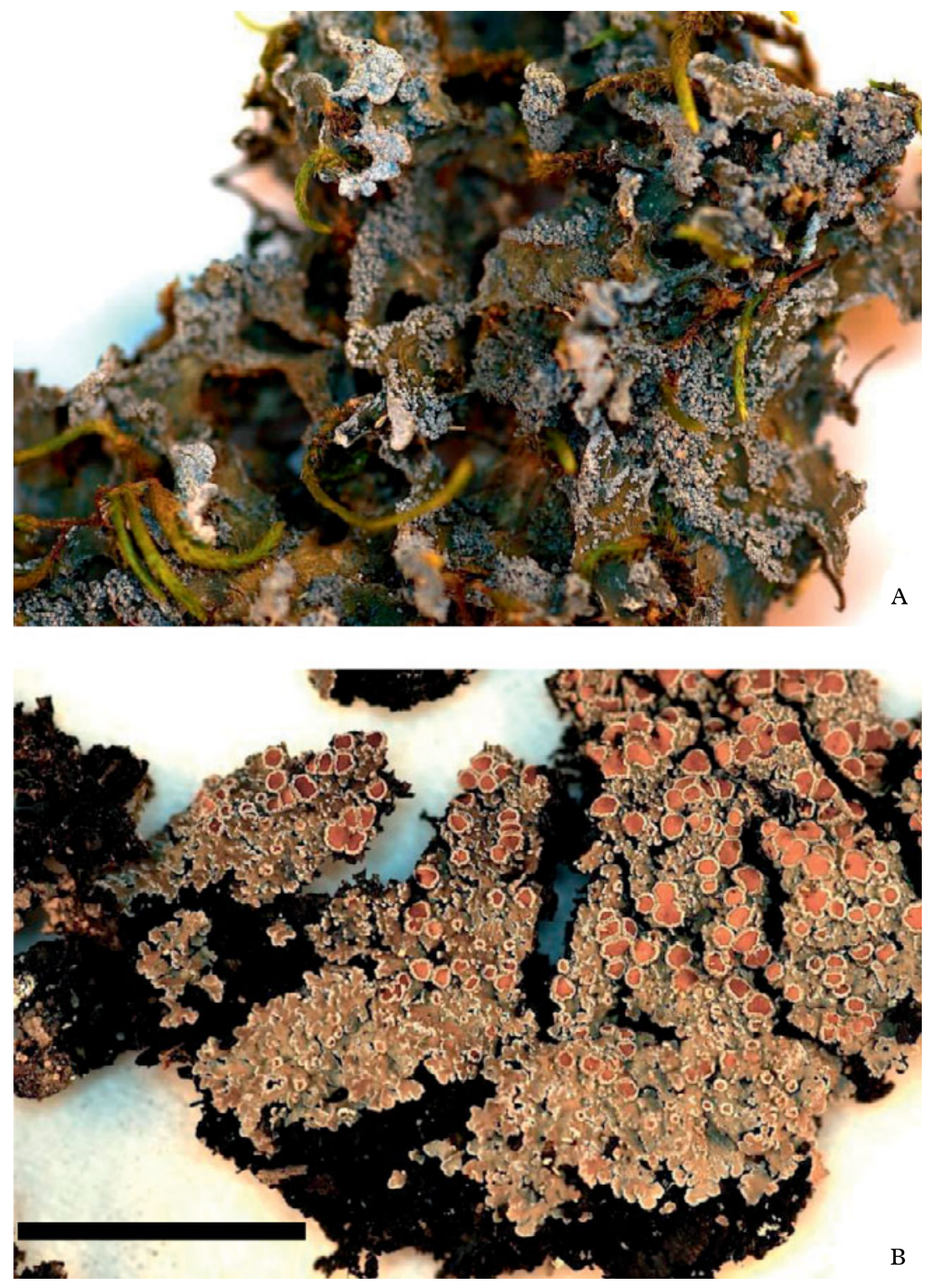

FIG. 2. Fuscopannaria, thalli of the species studied; A, F. (Kroswia) crystallifera; B, F. leucosticta. Scale $=1 \mathrm{~cm}$. In colour online.

2008 was conducted with our colleagues and friends Maarten Brand and Pieter van den Boom. The field trip to Madagascar was organized with the logistical support of the "Parc Botanique et Zoologique de Tsimbazaza" in Antananarivo, and with collecting and export permits of scientific material issued by the "Ministère des Eaux \&
Forêts"; it was organized with our colleagues and friends Damien Ertz, Eberhard Fischer, Dorothee Killmann and Tahina Razafindrahaja. We thank them all very warmly. We further thank the curators of the following herbaria for the loan of type collections or relevant material: $\mathrm{H}$, US. In addition, we thank $\mathrm{Mr}$ I. Cremasco and 
L. Gohy for technical assistance in the molecular laboratory and herbarium at the University of Liège. Prof. A. Elvebakk recently corresponded with us regarding the generic status of several clades within the Pannariaceae and we thank him very warmly for providing us with interesting clues and hypotheses. Nicolas Magain acknowledges financial support from FRIA, an organization of the Belgian Scientific Research Foundation. Finally we warmly thank both referees (Arve Elvebakk and Mats Wedin) for their critical and helpful notes and suggestions.

\section{REFERENCES}

Baloch, E. \& Grube, M. (2006) Evolution and phylogenetic relationships within Porinaceae (Ostropomycetidae), focusing on foliicolous species. Mycological Research 110: 125-136.

Carlsen, T., Bendiksby, M., Hofton, T. H., Reiso, S., Bakkestuen, V., Haugan, R., Kauserud, H. \& Timdal, E. (2012) Species delimitation, bioclimatic range, and conservation status of the threatened lichen Fuscopannaria confusa. Lichenologist 44: 565575.

Casano, L. M., del Campo, E. M., Garcia-Breijo, F. J., Reig-Armiñana, J., Gasulla, F., Del Hoyo, A., Guéra, A. \& Barreno, E. (2011) Two Trebouxia algae with different physiological performances are ever-present in lichen thalli Ramalina farinacea. Coexistence versus competition? Environmental Microbiology 13: 806-818.

Del Campo, E. M., Catalá, S., Gimeno, J., del Hoyo, A., Martínez-Alberola, F., Casano, L. M., Grube, M. \& Barreno, E. (2013) The genetic structure of the cosmopolitan three-partner lichen Ramalina farinacea evidences the concerted diversification of symbionts. FEMS Microbiology Ecology 83: 310-323.

Ekman, S., Wedin, M., Lindblom, L. \& Jørgensen, P. M. (2014) Extended phylogeny and a revised generic classification of the Pannariaceae. Lichenologist 46: 627-656.

Elvebakk, A., Robertsen, E. H., Park, C. H. \& Hong, S. G. (2010) Psorophorus and Xanthopsoroma, two new genera for yellow-green, corticolous and squamulose lichen species, previously in Psoroma. Lichenologist 42: 563-585.

Fernández-Mendoza, F., Domaschke, S., García, M. A., Jordan, P., Martín, M. P. \& Printzen, C. (2011) Population structure of mycobionts and photobionts of the widespread lichen Cetraria aculeata. Molecular Ecology 20: 1208-1232.

Henskens, F. L., Green, T. G. \& Wilkins, A. (2012) Cyanolichens can have both cyanobacteria and green algae in a common layer as major contributors to photosynthesis. Annals of Botany 110: 555563.

Huelsenbeck, J. P. \& Ronquist, F. (2001) MRBAYES: Bayesian inference of phylogenetic trees. Bioinformatics 17: 754-755.
Jørgensen, P. M. (2002) Kroswia, a new genus in the Pannariaceae (lichenized ascomycetes). Lichenologist 34: 297-303.

Jørgensen, P. M. (2003) Conspectus familiae Pannariaceae (Ascomycetes lichenosae). Ilicifolia 4: 1-79.

Jørgensen, P. M. (2007a) New discoveries in Asian pannariaceous lichens. Lichenologist 39: 235-243.

Jørgensen, P. M. (2007b) Pannariaceae. Nordic Lichen Flora 3: 96-112.

Jørgensen, P. M. \& Gjerde, I. (2012) Notes on some pannariaceous lichens from New Caledonia. Cryptogamie, Mycologie 33: 3-9.

Jørgensen, P. M. \& Sipman, H. (2006) The lichen family Pannariaceae in the montane regions of New Guinea. Fournal of the Hattori Botanical Laboratory 100: 695720 .

Jørgensen, P. M. \& Wedin, M. (1999) On Psoroma species from the Southern Hemisphere with cephalodia producing vegetative dispersal units. Lichenologist 31: 341-347.

Jørgensen, P. M., Ekman, S. \& Wedin, M. (2013) (2143) Proposal to conserve the name Fuscopannaria against Moelleropsis (lichenized Ascomycota). Taxon 62: 629.

Lanfear, R., Calcott, B., Ho, S. Y. \& Guindon, S. (2012) PartitionFinder: combined selection of partitioning schemes and substitution models for phylogenetic analyses. Molecular Biology and Evolution 29: 1695-1701.

Maddison, D. \& Maddison, W. (2005) MacClade v. 4.08. Sunderland, Massachusetts: Sinauer Associates.

Magain, N. \& Sérusiaux, E. (2014) Do photobiont switch and cephalodia emancipation act as evolutionary drivers in the lichen symbiosis? A case study in the Pannariaceae (Peltigerales). PLoS ONE 9(2): e89876.

Miądlikowska, J., Kauff, F., Hofstetter, V., Fraker, E., Grube, M., Hafellner, J., Reeb, V., Hodkinson, B. P., Kukwa, M., Lücking, R. et al. (2006) New insights into classification and evolution of the Lecanoromycetes (Pezizomycotina, Ascomycota) from phylogenetic analyses of three ribosomal RNA- and two protein-coding genes. Mycologia 98: 1088-1103.

Miller, M. A., Pfeiffer, W. \& Schwartz, T. (2010) Creating the CIPRES Science Gateway for inference of large phylogenetic trees. In Proceedings of the Gateway Computing Environments Workshop (GCE), 14 November 2010, New Orleans, Louisiana, pp. 1-8.

Nelsen, M. P. \& Gargas, A. (2008) Dissociation and horizontal transmission of codispersing lichen symbionts in the genus Lepraria (Lecanorales: Stereocaulaceae). New Phytologist 177: 264-275.

Nylander, J. A., Wilgenbusch, J. C., Warren, D. L. \& Swofford, D. L. (2008) AWTY (are we there yet?): a system for graphical exploration of MCMC convergence in Bayesian phylogenetics. Bioinformatics 24: 581-583.

Otálora, M. A. G., Aragón, G., Molina, M. C., Martínez, I. \& Lutzoni, F. (2010) Disentangling the CollemaLeptogium complex through a molecular phylogenetic study of the Collemataceae (Peltigerales, lichen-forming Ascomycota). Mycologia 102: 279-290. 
Passo, A., Stenroos, S. \& Calvelo, S. (2008) Foergensenia, a new genus to accommodate Psoroma cephalodinum (lichenized Ascomycota). Mycological Research 112: 1465-1474.

Printzen, C., Domaschke, S., Fernández-Mendoza, F. \& Pérez-Ortega, S. (2013) Biogeography and ecology of Cetraria aculeata, a widely distributed lichen with a bipolar distribution. MycoKeys 6: 33-53.

Rambaut, A. \& Drummond, A. (2007) Tracer. Version 1.5. Available at http://tree.bio.ed.ac.uk

Stamatakis, A. (2006) RAxML-VI-HPC: maximum likelihood-based phylogenetic analyses with thousands of taxa and mixed models. Bioinformatics 22: 2688-2690.
Stamatakis, A., Hoover, P. \& Rougemont, J. (2008) A rapid bootstrap algorithm for the RAxML Web servers. Systematic Biology 57: 758-771.

Wedin, M., Wiklund, E., Jørgensen, P. M. \& Ekman, S. (2009) Slippery when wet: phylogeny and character evolution in the gelatinous cyanobacterial lichens (Peltigerales, Ascomycetes). Molecular Phylogenetics and Evolution 53: 862-871. 